\title{
Model Fuzzy Tsukamoto untuk Klasifikasi dalam Prediksi Krisis Energi di Indonesia
}

\author{
Tsukamoto Fuzzy Model for Classification in Indonesia Energy Crisis \\ Prediction
}

\author{
Achmad Zaki*1, Heru Agus Santoso ${ }^{2}$ \\ ${ }^{1,2}$ JurusanTeknik Informatika, Universitas Dian Nuswantoro Semarang \\ E-mail: *1 achmadzaki93@ymail.com, ${ }^{2}$ heru.agus.santoso@dsn.dinus.ac.id
}

\begin{abstract}
Abstrak
Krisis energi dunia juga terjadi di Indonesia. Cadangan energi di Indonesia terutama energi fosil (minyak bumi, batubara, dan gas alam) semakin hari semakin menyusut. Ketersediaan akan energi fosil juga semakin berkurang karena peningkatan konsumsi energi per kapita. Untuk memprediksi krisis energi di Indonesia, paper ini mengusulkan pengembangan sistem inferensi fuzzy sukamoto untuk klasifikasi krisis energi berdasarkan parameter jumlah produksi, konsumsi energi dan faktor penggerak kebutuhan energi, yakni GDP dan populasi penduduk. Luaran dari sistem ini adalah klasifikasi berdasarkan parameter tersebut, yaitu kondisi aman, waspada dan krisis. Hasil eksperimen menunjukan sistem yang dibangun menghasilkan tingkat akurasi pada minyak bumi 90\%, batubara $100 \%$ dan gas alam $100 \%$. Dengan adanya sistem ini diharapkan mampu memberikan peringatan dini dan pendukung keputusan bagi pemerintah atau pihak instansi terkait dalam memberikan penangan atau solusi terhadap masalah krisis energi.
\end{abstract}

Kata Kunci - Krisis Energi, Sistem Inferensi Fuzzy, Tsukamoto, Klasifikasi.

\begin{abstract}
World energy crisis also occurred in Indonesia. Energy reserves in Indonesia, especially fossil fuels (petroleum, coal, and natural gas) are increasingly shrinking. The availability of fossil energy will also be on the wane because of an increase in energy consumption per capita. To predict the energy crisis in Indonesia, this paper proposes the development of sukamoto fuzzy inference systems for classification energy crisis based on parameters the amount of production, energy consumption and energy demand driven factors, namely GDP and population. Outcomes of this system is the classification based on these parameters, i.e., a safe condition, alert and crisis. The experimental results show the system produce levels of accuracy at $90 \%$ petroleum, natural gas $100 \%$ and CoA, 100\%. This system are expected to provide an early warning and decision support for the government or the relevant agencies in giving the handlers or the solution to the problem of energy crisis.
\end{abstract}

Keywords - Energy crisis, Fuzzy Inference System, Tsukamoto, Classification. 


\section{PENDAHULUAN}

Menurut Steven Fink krisis merupakan keadaan yang tidak stabil dimana perubahan yang cukup signifikan mengancam, baik perubahan yang tidak diharapkan ataupun perubahan yang diharapkan akan memberikan hasil yang lebih baik. Steven Fink mengidentikkan suatu krisis seperti layaknya penyakit yang menyerang tubuh manusia. Terminologi yang digunakannya untuk mendiagnosis gejala krisis sama seperti terminologi yang digunakan dalam dunia kedokteran untuk mengukur tingkat atau stadium suatu krisis [1].

Campbell, Reece dan Mitchell berpendapat bahwa pengertian energi ialah kemampuan untuk mengatur ulang suatu materi. Ringkasnya energi adalah kapasitas atau kemampuan melaksanakan kerja. Sumantoro berpendapat energi adalah kemampuan untuk melakukan usaha seperti mendorong atau menggerakkan suatu benda. Dari berbagai pengertian dan definisi energi diatas dapat disimpulkan bahwa secara umum energi dapat didefinisikan sebagai kekuatan yang dimilki oleh suatu benda sehingga mampu untuk melakukan kerja.

Yang termasuk bahan bakar fosil terdiri dari 3 jenis yaitu minyak bumi, gas alam dan batubara. Minyak bumi adalah suatu bahan bakar yang terbuat dari fosil. Disebut suatu bahan bakar fosil sebab dibentuk dari sisa binatang dan tumbuhan laut kecil atau organisme organisme yang telah punah berjuta-juta tahun yang lalu. Ketika organisme tersebut mati, mereka tenggelam di dasar samudra. Di sini mereka terkubur oleh lapisan-lapisan pasir dan lanau. Dari waktu ke waktu, campuran organik ini mengalami tekanan yang sangat besar, dan panas yang meningkat. Campuran dibuat dari atom karbon hidrokarbon dan hidrogen yang akhirnya minyak memenuhi batuan seperti spons yang basah [2]. Gas Alam Merupakan gas yang diperoleh dari reservoir alami bawah tanah baik sebagai gas bebas maupun sebagai gas yang berkaitan dengan minyak bumi. Mengandung sebagian besar gas methane $(\mathrm{CH} 4)$ dan hidrokarbon lainnya dalam jumlah sedikit Mengandung impuritas seperti $\mathrm{H} 2 \mathrm{~S}, \mathrm{~N} 2$, dan $\mathrm{CO} 2$ yang bercampur dengan gas alam tersebut, pada umumnya jenuh dengan uap air [3]. Batubara adalah sisa tumbuhan dari jaman prasejarah yang berubah bentuk yang awalnya berakumulasi dirawa dan lahan gambut. Penimbunan lanau dan sedimen lainnya, bersama dengan pergeseran kerak bumi (dikenal sebagai pergeseran tektonik) mengubur rawa dan gambut yang seringkali sampai ke kedalaman yang sangat dalam. Dengan penimbunan tersebut, material tumbuhan tersebut terkena suhu dan tekanan yang tinggi. Suhu dan tekanan yang tinggi tersebut menyebabkan tumbuhan tersebut mengalami proses perubahan fisika dan kimiawi dan mengubah tumbuhan tersebut menjadi gambut dan kemudian batubara [4].

Ketahanan energi di Tanah Air telah berada di titik kritis. Produksi minyak nasional terus menurun seiring bertambahnya usia sumur-sumur minyak yang ada. Di lain pihak, kebutuhan bahan bakar minyak di kalangan masyarakat kian tinggi sebagai dampak pesatnya pertumbuhan ekonomi. Maka, Indonesia pun kini menjadi negara importir minyak. Krisis energi terjadi karena meningkatnya kebutuhan/permintaan akan energi, berbanding terbalik dengan jumlah produksi energi dalam negeri yang semakin menurun. Faktor penggerak naiknya kebutuhan/permintaan akan energi ini adalah GDP (Gross Domestic Product), populasi penduduk [5].

Kata sistem berasal dari bahasa Yunani yaitu kumpulan elemen yangsaling berkait dan bertanggung jawab memproses masukan (input) sehingga menghasilkan keluaran (output). Inferensi adalah tindakan atau proses yang berasal kesimpulan logis dari premis-premis yang diketahui atau dianggap benar. Kesimpulan yang ditarik juga disebut sebagai idiomatik. Hukum valid inference dipelajari dalam bidang logika. Jadi Sistem inferensi fuzzy (FIS) adalah sebuah framework komputasi populer berdasarkan pada konsep teori himpunan fuzzy, aturan if - then fuzzy, dan penalaran fuzzy [6]. Pada penelitin ini, dikembangkan suatu sistem inferensi fuzzy metode tsukamoto yang mampu mengklasifikasikan krisis energi berdasarkan parameter jumlah produksi dan konsumsi suatu energi dan faktor penggerak kebutuhan energi, yakni GDP dan populasi penduduk. 


\section{METODE PENELITIAN}

\subsection{Logika Fuzzy}

Konsep tentang logikafuzzy diperkenalkan oleh Prof. Lotfi Astor Zadeh pada 1962. Logika Fuzzy adalah metodologi sistem kontrol pemecahan masalah, yang cocok untuk diimplementasikan pada sistem, mulai dari sistem yang sederhana, sistem kecil, embedded system, jaringan PC, multi-channel atau workstation berbasis akuisi data, dan sistem control [7].

Metodologi ini dapat diterapkan diperangkat keras, perangkat lunak, atau kombinasi keduanya. Dalam logika klasik dinyatakan bahwa segala sesuatu bersifat biner, yang artinya adalah hanya mempunyai dua kemungkinan, "Ya atau Tidak ", "Benar atau Salah", "Baik atau Buruk", dan lain-lain. Oleh karena itu, semua ini dapat mempunyai nilai keanggotaan 0 atau 1. Akan tetapi, dalam logika fuzzy memungkinkan nilai keanggotaan berada diantara 0 dan 1 . Artinya, bisa saja suatu keadaan mempunyai dua nilai "Ya dan Tidak", "Benar atau Salah", "Baik atau Buruk" secara bersamaan, namun besar nilainya tergantung pada bobot keanggotaan yang dimiliknya [7]. Bila dibandingkan dengan logika konvensional, kelebihan logika fuzzy adalah kemampuannya dalam proses penalaran secara bahasa sehingga dalam perancangannya tidak memerlukan persamaan matematik yang rumit [7].

\subsection{Operasi Himpunan Fuzzy}

Operasi himpunan fuzzy diperlukan untuk proses inferensi atau penalaran. Dalam hal ini yang dioperasikan adalah derajat keanggotaannya. Berikut beberapa operasi dasar yang paling sering digunakan untuk mengombinasi dan memodifikasi himpunan fuzzy [6].

\subsubsection{Operasi Gabungan (Union)}

Operasi gabungan (sering disebut sebagai operator OR) dari himpunan fuzzy A dan B dinyatakan sebagai AUB.

\subsubsection{Operasi Irisan (Intersection)}

Operasi irisan (sering disebut sebagai operator AND) dari himpunan fuzzy A dan B dinyatakan sebagai $\mathrm{A} \cap \mathrm{B}$.

\subsubsection{Operator komplemen}

Bila himpunan fuzzy A pada himpunan universal X mempunyai fungsi keanggotaan $\mu \mathrm{A}(\mathrm{x})$ maka komplemen dari himpunan fuzzy $\mathrm{A}$ (sering disebut NOT) adalah himpunan fuzzy $\mathrm{A}^{\mathrm{C}}$ dengan fungsi keanggotaan untuk setiap x elemen X.

Dalam basis pengetahuan fuzzy, tiap-tiap rule selalu berhubungan dengan relasi fuzzy. Dalam fungsi implikasi biasanya digunakan sebagai berikut:

IF $\mathrm{x}$ is $\mathrm{A}$ THEN $\mathrm{y}$ is $\mathrm{B}$ 


\subsection{Cara Kerja Logika Fuzzy}

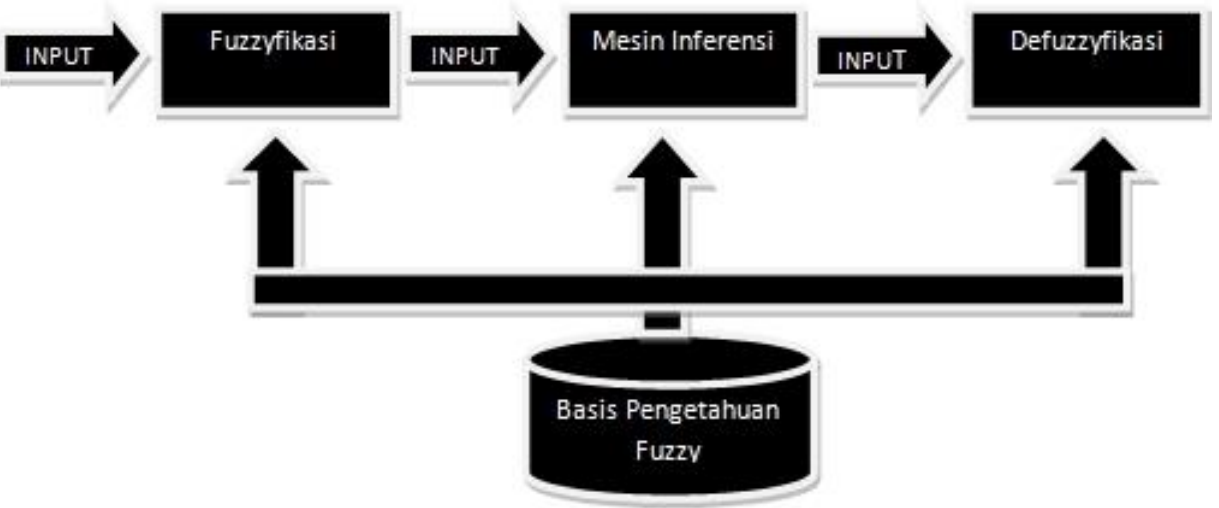

Gambar 1. Cara Kerja Logika Fuzzy ini:

Dalam inferensinya, metode tsukamoto menggunakan tahapan-tahapan sebagai berikut

1. Fuzzyfikasi.

2. Pembentukan basis pengetahuan Fuzzy (rule dalam bentuk $I F$...THEN).

3. Aplikasi fungsi implikasi menggunakan fungsi MIN untuk mendapatkan nilai $\alpha$-predikat tiap tiap rule $(\alpha 1, \alpha 2, \alpha 3, \ldots$ an) kemudian masing-masing nilai $\alpha$-predikat ini digunakan untuk menghitung keluaran hasil inferensi secara tegas (crisp) masing - masing rule (z1, z2, $\mathrm{z} 3, \ldots \mathrm{zn})$.

4. Defuzzyfikasi menggunakan metode Rata-rata.

$$
Z^{*}=\Sigma \alpha 1 z 1 / \Sigma \alpha 1
$$
pembobotan:

Proses defuzzyfikasi hasil berupa output (z) diperoleh dengan menggunakan rata-rata

$$
\mathrm{Z}=\alpha 1 \mathrm{z} 1+\alpha 2 \mathrm{z} 2 / \alpha 1+\alpha 2
$$

Fungsi keanggotaan (membership function) adalah grafik yang mewakili besar dari derajat keanggotaan masing-masing variabel input yang berada dalam interval antara 0 dan 1 . Derajat keanggotaan sebuah variabel $\mathrm{x}$ dilambangkan dengan simbol $\mu(\mathrm{x})$.

\subsection{Model Masukan dan Keluaran Sistem}

Mendefinisikan model masukan dan keluaran sistem, dalam kasus krisis energi ini terdapat 4 Variabel sebagai berikut:

\subsubsection{Masukan}

Empat variabel masukan fuzzy inferensi prediksi krisis energi Indonesia adalah variabel produksi, konsumsi, GDP dan jumlah penduduk. Nilai variabel produksi dan nilai variabel konsumsi energi pada Tabel 1 dan Tabel 2 diperoleh dari BP Statistical Review of World Energy dengan alamat website http://www.bp.com/statisticalreview. Sedangkan nilai variabel GDP dan nilai variabel jumlah penduduk pada Tabel 3 dan Tabel 4 diperoleh dari United State Departement of Agriculture (USDA) dengan alamat website : http://www.usda.gov.

Tabel 1. Variabel Produksi

\begin{tabular}{|c|c|c|c|}
\hline Variabel & Minyak Bumi & Gas Alam & Batubara \\
\hline Produksi & $0-115$ & $0-120$ & $0-150$ \\
\hline
\end{tabular}


Citec Journal, Vol. 3, No. 3, Mei 2016 - Juli 2016

Tabel 2. Variabel Konsumsi

\begin{tabular}{|c|c|c|c|}
\hline Variabel & Minyak Bumi & Gas Alam & Batubara \\
\hline Konsumsi & $0-115$ & $0-120$ & $0-150$ \\
\hline
\end{tabular}

Tabel 3. Variabel GDP

\begin{tabular}{|l|l|}
\hline \multicolumn{1}{|c|}{ Variabel } & \multicolumn{1}{c|}{ Bobot (million dolar) } \\
\hline Low & $0-35$ \\
\hline Moderat & $80-250$ \\
\hline High & $197-750$ \\
\hline
\end{tabular}

Tabel 4. Variabel Penduduk

\begin{tabular}{|l|l|}
\hline \multicolumn{1}{|c|}{ Variabel } & \multicolumn{1}{c|}{ Bobot (million) } \\
\hline Rendah & $0-122$ \\
\hline Sedang & $122-243$ \\
\hline Tinggi & $214-285$ \\
\hline
\end{tabular}

\subsubsection{Keluaran}

Tabel 5 merupakan variabel luaran tingkat krisis dengan bobot antara 0-1, yaitu kondisi aman, waspada dan krisis.

Tabel 5. Variabel Tingkat Krisis

\begin{tabular}{|l|l|}
\hline \multicolumn{1}{|c|}{ Variabel } & \multicolumn{1}{c|}{ Bobot (million) } \\
\hline Aman & $0-0.4$ \\
\hline Waspada & $0.5-0.9$ \\
\hline Krisis & $0.9-1$ \\
\hline
\end{tabular}

\subsection{Dekomposisi variabel model menjadi himpunan fuzzy}

Dari variable-variabel masukan dibentuk himpunan fuzzy antara lain:

1. Variabel Produksi

Variabel Produksi ada 3 macam yaitu Minyak Bumi, Gas Alam \& Batubara yang masingmasing memiliki 3 himpunan fuzzy (Rendah, Sedang, Tinggi). Fungsi keanggotaan produksi minyak bumi ditunjukkan pada Gambar 2. Fungsi keanggotaan produksi batubara ditunjukkan pada Gambar 3. Sedangkan fungsi keanggotaan produksi gas alam ditunjukkan pada Gambar 4.

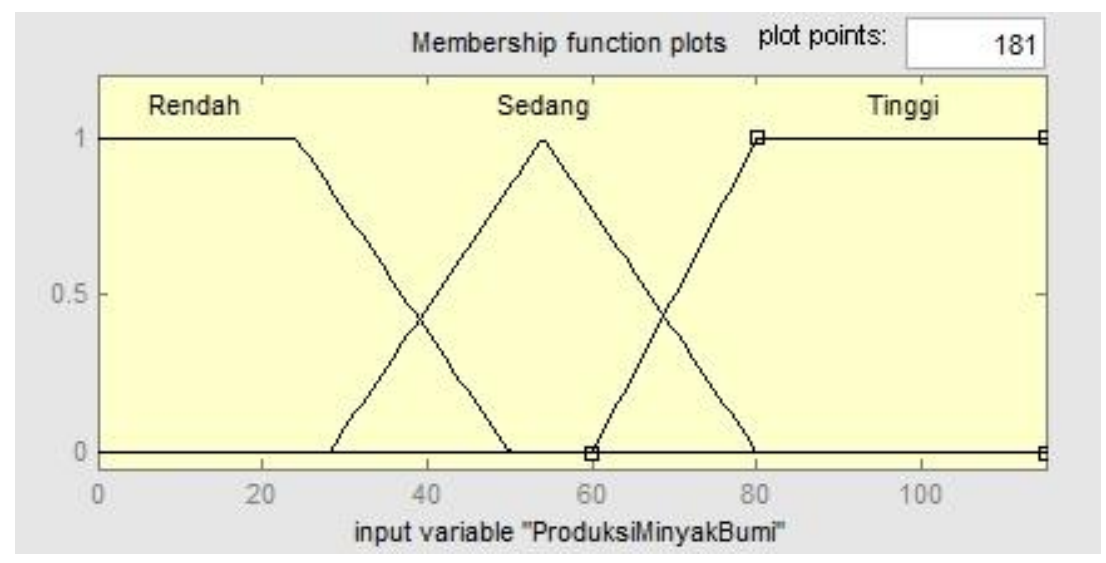

Gambar 2. Produksi Minyak Bumi 
Fungsi Keanggotaan:

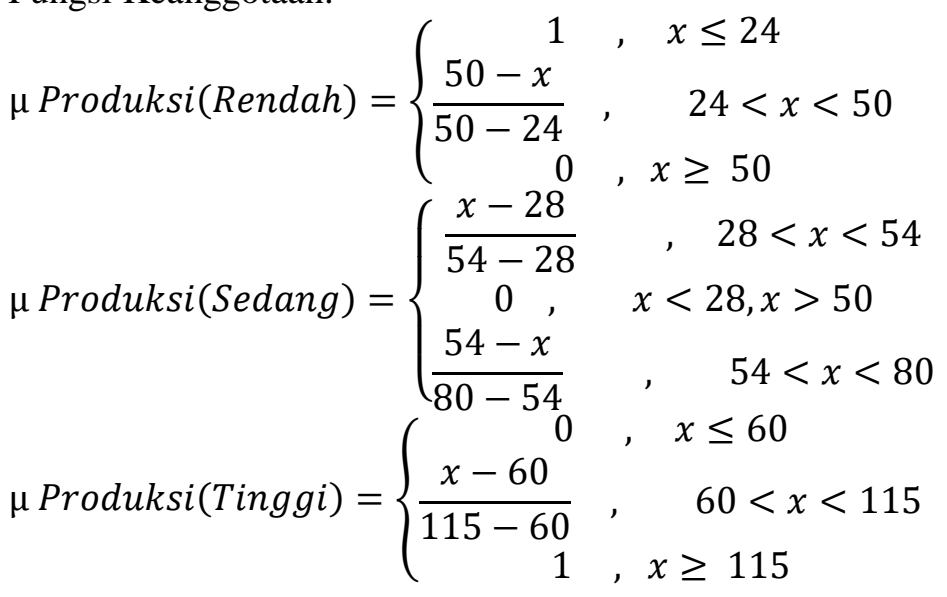

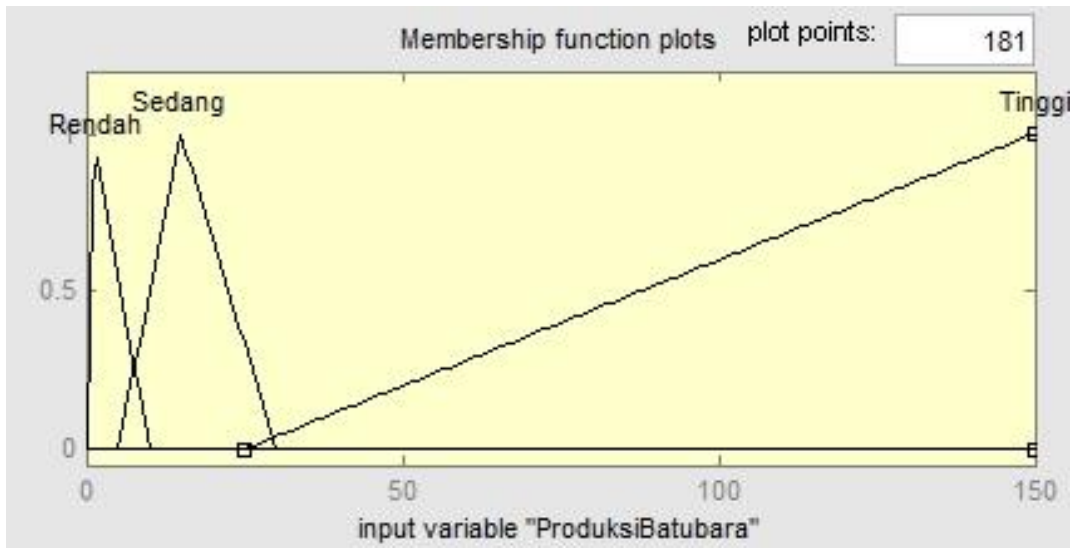

Gambar 3. Produksi Batubara

Fungsi Keanggotaan:

$\mu$ Produksi(Rendah) $=\left\{\begin{aligned} 1, & x \leq 1 \\ \frac{10-x}{10-1}, & 1<x<10 \\ 0, & x \geq 10\end{aligned}\right.$

$\mu$ Produksi(Sedang) $\left\{\begin{array}{cc}\frac{x-5}{15-5} & , \quad 5<x<15 \\ 0, & x<5, x>30 \\ \frac{30-x}{30-15} & , \quad 15<x<30\end{array}\right.$

$\mu$ Produksi(Tinggi $)=\left\{\begin{array}{rc}0 & , \quad x \leq 150 \\ \frac{x-25}{150-25}, & 25<x<150 \\ 1 & , x \geq 150\end{array}\right.$ 
Citec Journal, Vol. 3, No. 3, Mei 2016 - Juli 2016

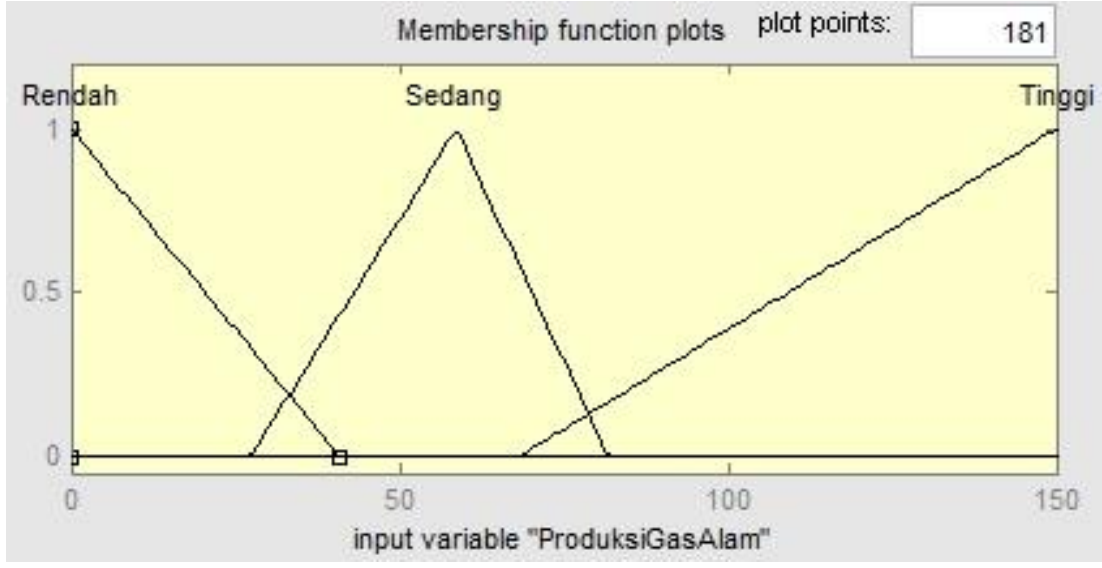

Gambar 4. Produksi Gas Alam

Fungsi Keanggotaan:

$\mu$ Produksi(Rendah $)=\left\{\begin{aligned} 1, & x \leq 1 \\ \frac{30-x}{30-1}, & 1<x<30 \\ 0, & x \geq 30\end{aligned}\right.$

$\mu$ Produksi(Sedang) $\left\{\begin{array}{cc}\frac{x-20}{43-20} & , 20<x<43 \\ 0, & x<20, x>60 \\ \frac{60-x}{60-43} & , \quad x \leq 110\end{array}\right.$

$\mu$ Produksi(Tinggi) $=\left\{\begin{aligned} 0 & , \quad x \leq 110 \\ \frac{x-50}{110-50}, & 50<x<110 \\ 1 & , x \geq 110\end{aligned}\right.$

2. Variabel Konsumsi

Variabel Konsumsi ada 3 macam yaitu Minyak Bumi, Gas Alam \& Batubara yang masing-masing memiliki 3 himpunan fuzzy (Rendah, Sedang, Tinggi). Fungsi keanggotaan konsumsi minyak bumi ditunjukkan pada Gambar 5. Fungsi keanggotaan konsumsi batubara ditunjukkan pada Gambar 6. Sedangkan fungsi keanggotaan konsumsi gas alam ditunjukkan pada Gambar 7.

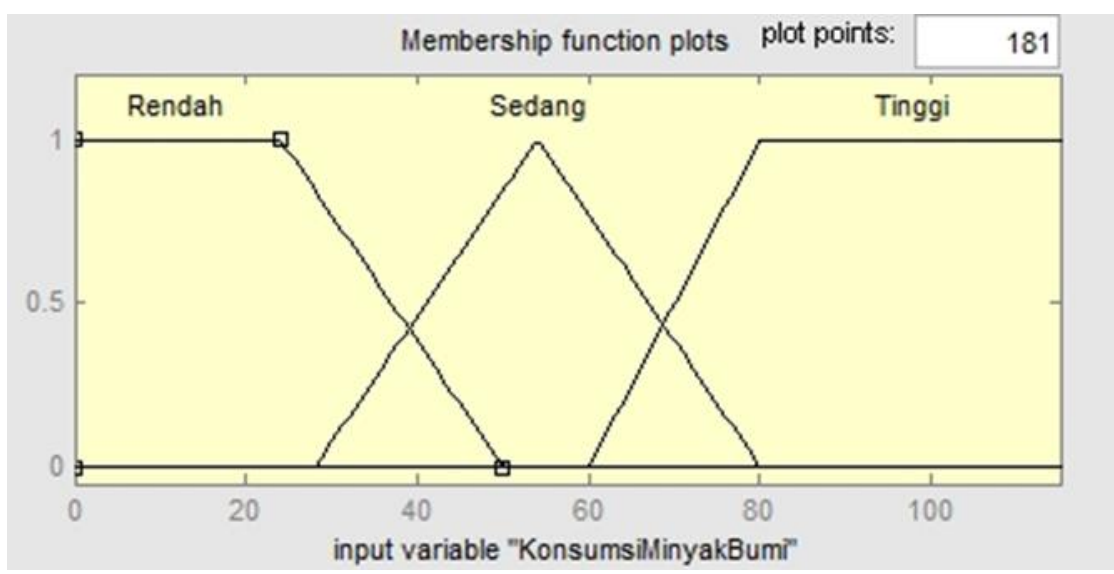

Gambar 5. Konsumsi Minyak Bumi 
Fungsi Keanggotaan:

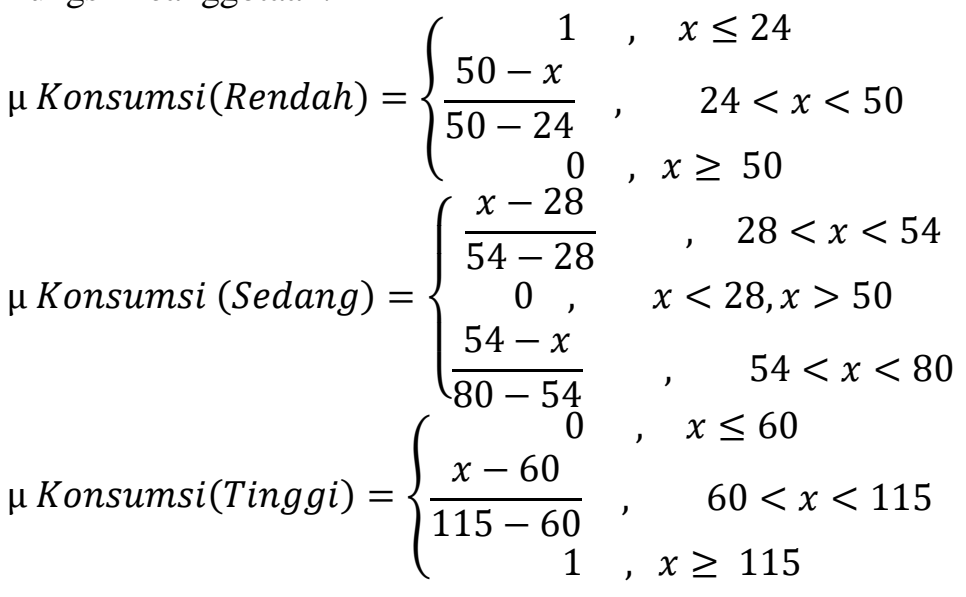

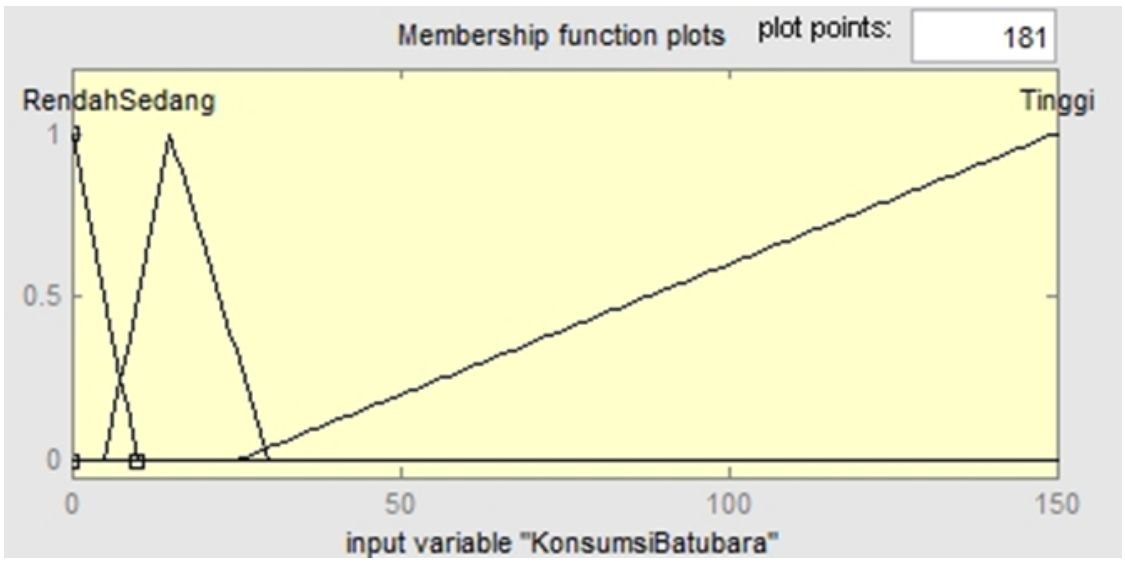

Gambar 6. Konsumsi Batubara

Fungsi Keanggotaan:

$\mu$ Produksi(Rendah) $=\left\{\begin{array}{cc}1, \quad x \leq 1 \\ \frac{10-x}{10-1}, 1<x<10 \\ 0, & x \geq 10\end{array}\right.$
$\mu$ Produksi(Sedang) $=\left\{\begin{array}{cc}\frac{x-5}{15-5}, \quad 5<x<15 \\ 0, & x<5, x>30 \\ \frac{30-x}{30-15} & , \quad 15<x<30\end{array}\right.$
$\mu$ Produksi(Tinggi) $=\left\{\begin{array}{cc}\frac{x-25}{150-25}, & 25<x<150 \\ 1 & , \quad x \geq 150\end{array}\right.$ 
Citec Journal, Vol. 3, No. 3, Mei 2016 - Juli 2016

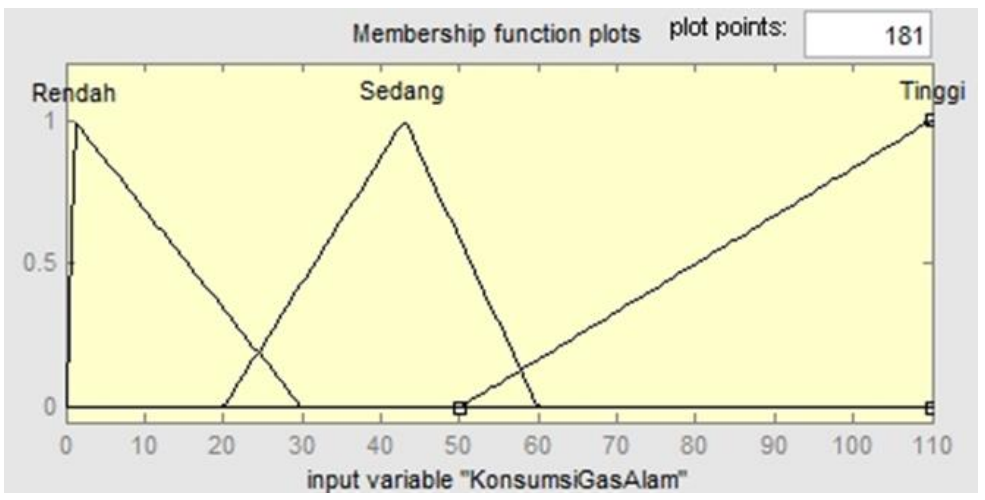

Gambar 7. Konsumsi Gas Alam

Fungsi Keanggotaan:

$\mu$ Konsumsi $($ Rendah $)=\left\{\begin{aligned} 1, & x \leq 1 \\ \frac{30-x}{30-1}, & 1<x<30 \\ 0, & x \geq 30\end{aligned}\right.$

$\mu$ Konsumsi(Sedang) $=\left\{\begin{array}{cc}\frac{x-20}{43-20} & , 20<x<43 \\ 0, & x<20, x>60 \\ \frac{60-x}{60-43} & , \quad 43<x<60\end{array}\right.$

$\mu$ Konsumsi $($ Tinggi $)=\left\{\begin{aligned} 0 & , \quad x \leq 110 \\ \frac{x-50}{110-50}, & 50<x<110 \\ 1 & , x \geq 110\end{aligned}\right.$

3. Variabel GDP

Fungsi keanggotaan GDP ditunjukkan pada Gambar 8.

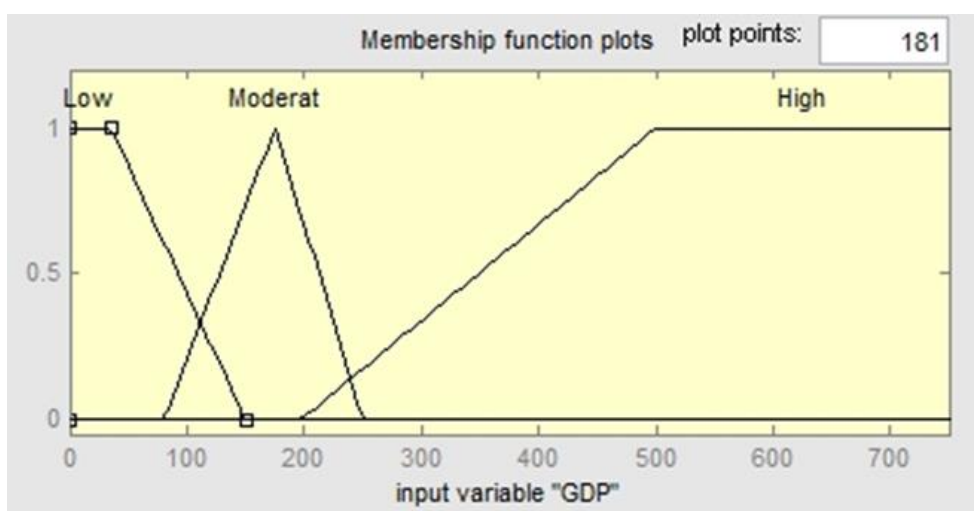

Gambar 8. GDP

Fungsi Keanggotaan:

$\mu G D P($ Low $)=\left\{\begin{aligned} 0 & , \quad x \leq 35 \\ \frac{150-x}{150-35}, & 35<x<150 \\ 1 & , \quad x \geq 150\end{aligned}\right.$ 
$\mu G D P($ Moderat $)=\left\{\begin{array}{cc}\frac{x-80}{175-80} & , 80<x<175 \\ 0, & x<80, x>250 \\ \frac{250-x}{250-175}, & 175<x<250 \\ 1, & 175\end{array}\right.$

$\mu G D P($ High $)=\left\{\begin{array}{rc}0, & x<197, x>750 \\ \frac{x-197}{750-197}, & 197<x<750 \\ 1 & , x=750\end{array}\right.$

4. Variabel Penduduk

Fungsi keanggotaan Penduduk ditunjukkan pada Gambar 9.

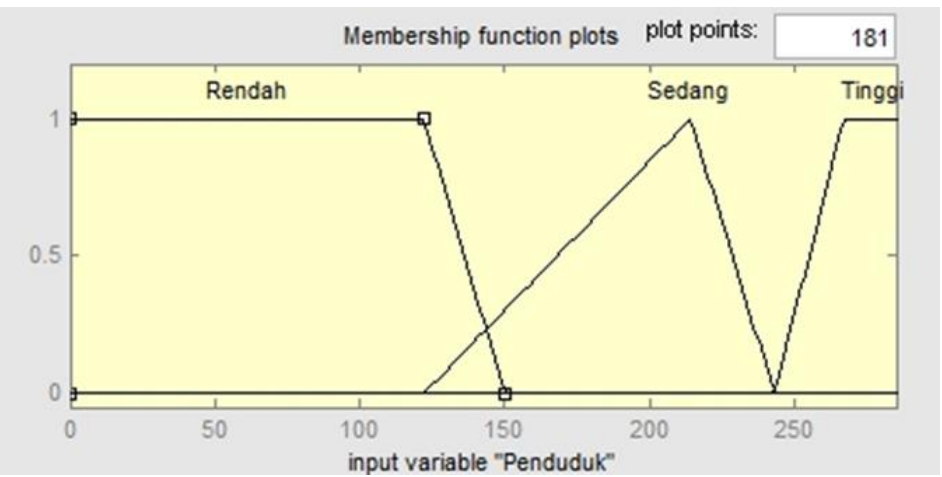

Gambar 9. Penduduk

Fungsi Keanggotan:

$\mu$ Penduduk $($ Rendah $)=\left\{\begin{aligned} 1, & x \leq 122 \\ \frac{150-x}{150-122}, & 122<x<150 \\ 0 & , x \geq 150\end{aligned}\right.$

$\mu$ Penduduk $($ Sedang $)=\left\{\begin{array}{ccc}\frac{x-122}{214-122} & , 122<x<214 \\ 0, & x<122, x>214 \\ \frac{243-x}{243-214} & , \quad 214<x<243\end{array}\right.$

$\mu$ Penduduk $($ Tinggi $)=\left\{\begin{aligned} 0, & x \leq 243 \\ \frac{x-243}{285-243}, & 243<x<285 \\ 1, & x \geq 285\end{aligned}\right.$ 
Citec Journal, Vol. 3, No. 3, Mei 2016 - Juli 2016

1. Tingkat Krisis

Dari variabel-variabel keluaran dibentuk himpunan fuzzy sebagai berikut.

Fungsi keanggotan Tingkat Kritis ditunjukkan pada Gamabr 10.

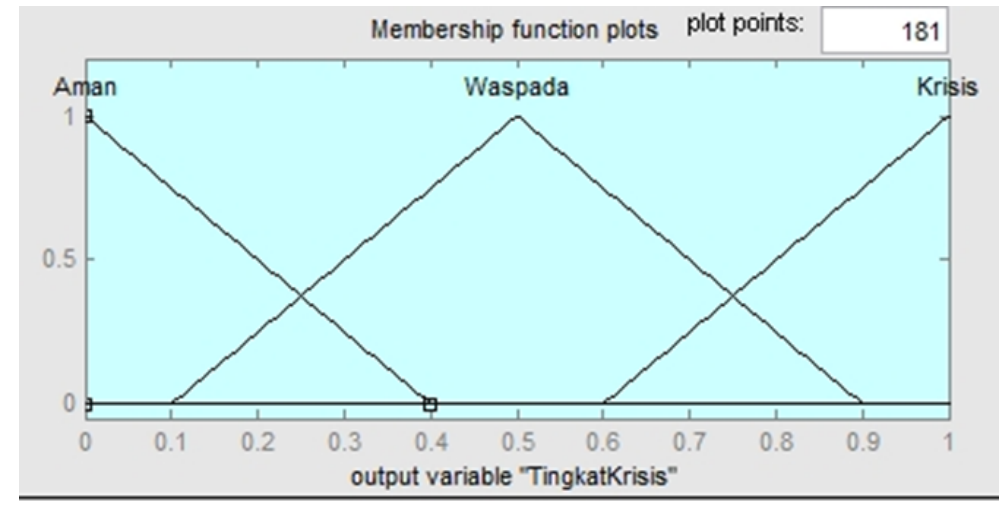

Gambar 10. Tingkat Krisis

Fungsi Keanggotaan:

$\mu$ TingkatKrisis (Aman) $=\left\{\begin{array}{rc}1, & x \leq 0 \\ \frac{0.4-x}{0.4-0}, & 0<x<0.4 \\ 0, & x \geq 0.4\end{array}\right.$

$\mu$ TingkatKrisis(Waspada) $=\left\{\begin{array}{cc}\frac{x-0.1}{0.4-0.1} & , 0.1<x<0.4 \\ 0, & x<0.1, x>0.9 \\ \frac{0.9-x}{0.9-0.5} & , \quad 0.5<x<0.9 \\ 1, & x=0.5\end{array}\right.$

$\mu$ TingkatKrisis(Krisis) $=\left\{\begin{array}{cc}\frac{x-0.6}{1-0.6}, & 0.6<x<1 \\ 1, & x \geq 1\end{array}\right.$

Dari ke empat variabel input dan sebuah variabel output yang telah didefinisikan, dengan melakukan analisa data dan konsultasi dengan staff Migas Dinas ESDM Provinsi Jawa Tengah menghasilkan 81 aturan.

\section{HASIL DAN PEMBAHASAN}

Untuk mempermudah proses klasifikasi prediksi krisis energi di Indonesia dan otomatisasi perhitungannya, maka peneliti mengembangkan aplikasinya dengan bahasa pemrograman Java. Gambar 11, 12, 13 dan Gambar 14 adalah desain input dan output aplikasi tersebut. Tampilan awal aplikasi ditunjukkan seperti pada Gambar 11. Form untuk mengitung prediksi krisis batubara ditunjukkan seperti pada Gambar 12. Form untuk mengitung prediksi krisis gas alam ditunjukkan seperti pada Gambar 13. Sedangkan form untuk mengitung prediksi krisis minyak bumi ditunjukkan seperti pada Gambar 14. 


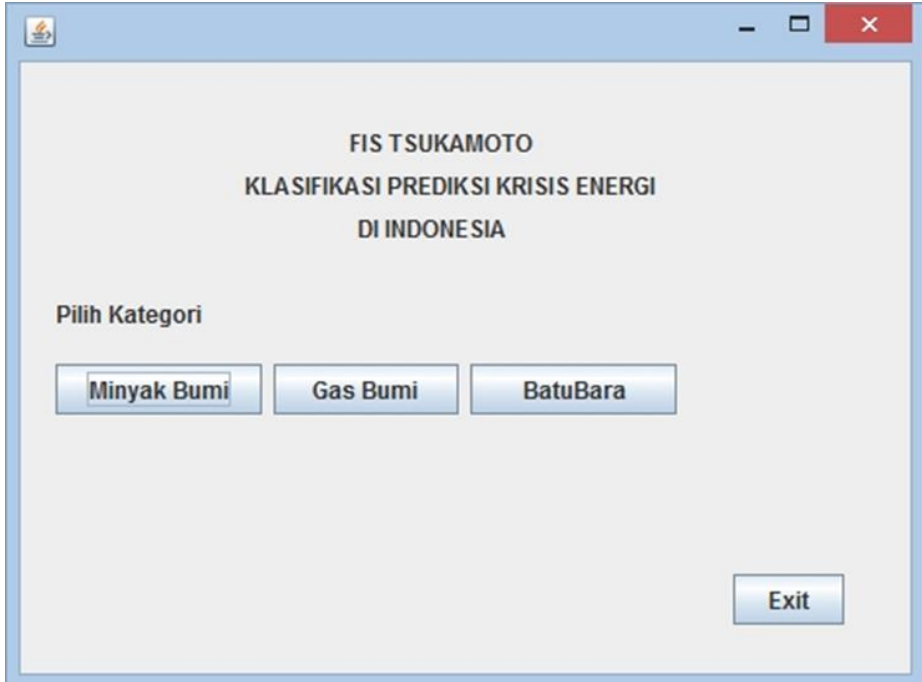

Gambar 11. Tampilan Awal

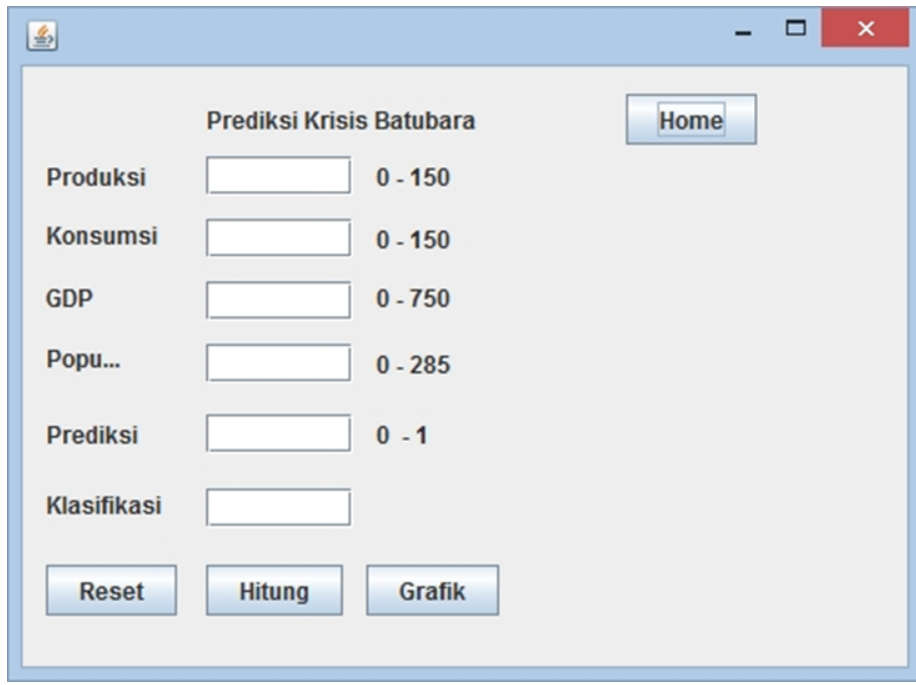

Gambar 12. Form Batubara

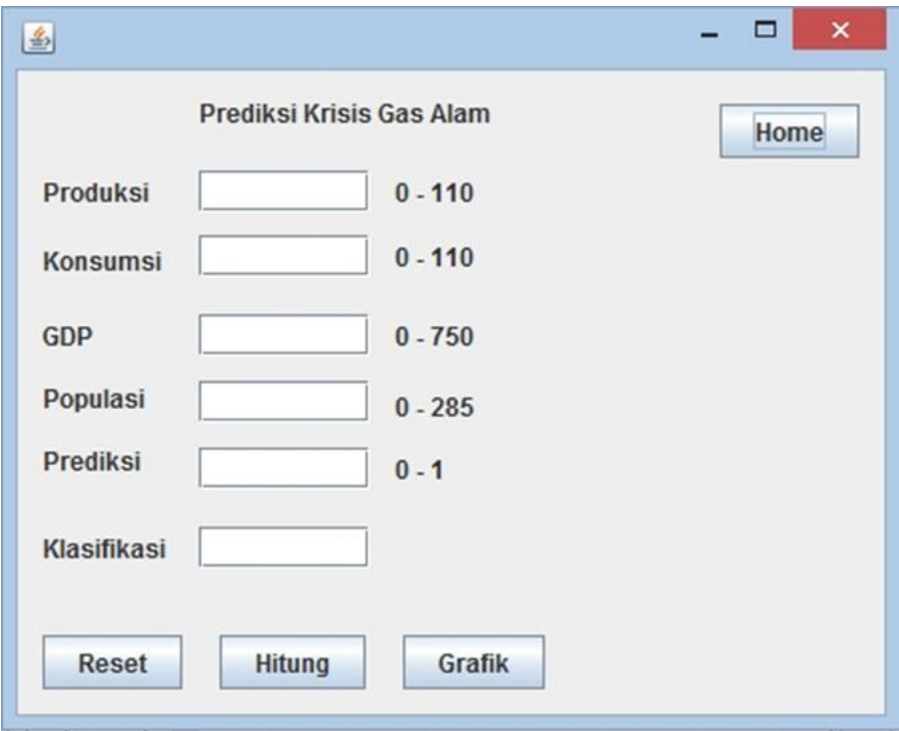


Citec Journal, Vol. 3, No. 3, Mei 2016 - Juli 2016

Gambar 13. Form Gas Alam

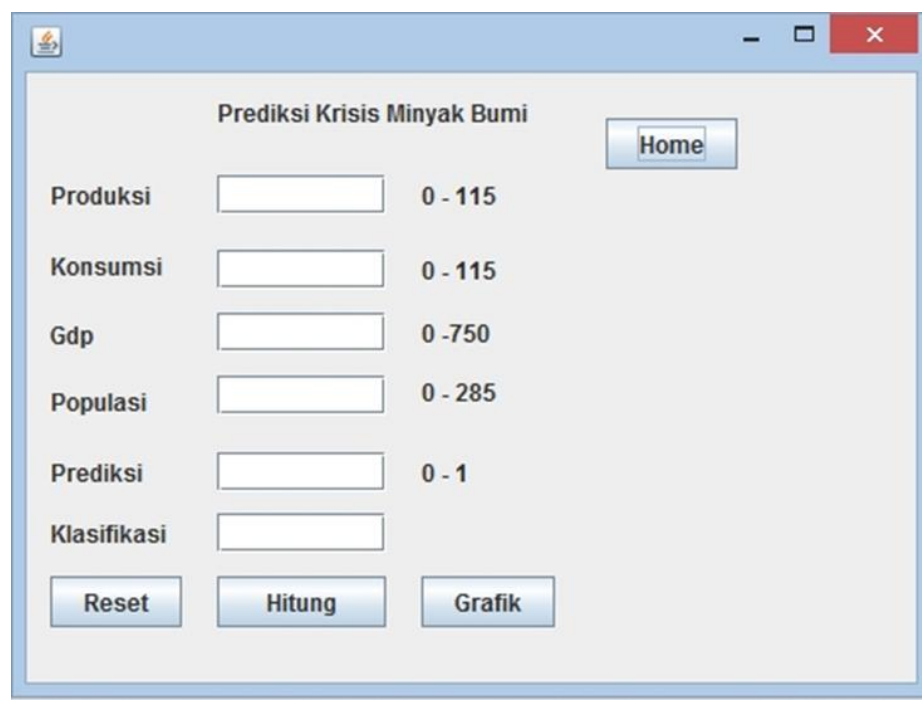

Gambar 14. Form Minyak Bumi

Berdasarkan luaran aplikasi yang sudah dibuat, diperoleh hasil prediksi krisis energi batubara, minyak bumi dan gas alam. Hasil prediksi tersebut ditampilkan pada Tabel 6, Tabel 7, dan Tabel 8 pada kolom "Klasifikasi". Sedangkan kondisi real diperoleh dari analisis laporan Energy-Economic Statistical Review pada alamat: http://www.bp.com/en/global/corporate/ energy-economics/statistical-review-of-world-energy/country-and-regional-insights/Indonesia sights.html.

Pada review tersebut dikatakan bahwa sampai dengan tahun 2014 produksi energi Indonesia meningkat $1.4 \%$, sementara konsumsi juga terus meningkat dari tahun ke tahun. Kondisi krisis energi di Indonesia tidak dijelaskan pada laporan tersebut, sehingga penulis menyimpulkan kondisi ini sebagai kondisi waspada.

Tabel 6. Akurasi Batubara

\begin{tabular}{|l|l|l|l|l|l|l|c|}
\hline $\begin{array}{c}\text { Data } \\
\text { Tahun }\end{array}$ & Produksi & Konsumsi & GDP & Populasi & $\begin{array}{c}\text { Tingkat } \\
\text { Krisis }\end{array}$ & Klasifikasi & Real \\
\hline 2005 & 93.9 & 24.4 & 285.87 & 229.244 & 0.589 & Waspada & Waspada \\
\hline 2006 & 119.2 & 28.9 & 301.59 & 232.199 & 0.567 & Waspada & Waspada \\
\hline 2007 & 133.4 & 36.2 & 320.73 & 235.098 & 0.768 & Waspada & Waspada \\
\hline 2008 & 147.8 & 31.5 & 340.02 & 237.98 & 0.742 & Waspada & Waspada \\
\hline 2009 & 157.6 & 33.2 & 355.58 & 240.714 & 0.763 & Waspada & Waspada \\
\hline 2010 & 169.2 & 39.5 & 377.28 & 243.42 & 0.8 & Waspada & Waspada \\
\hline 2011 & 217.3 & 46.9 & 401.66 & 246.05 & 0.64 & Waspada & Waspada \\
\hline 2012 & 237.3 & 53.0 & 426.36 & 248.645 & 0.768 & Waspada & Waspada \\
\hline 2013 & 276.2 & 57.6 & 451.82 & 251.16 & 0.742 & Waspada & Waspada \\
\hline 2014 & 281.7 & 60.8 & 479.56 & 253.6 & 0.743 & Waspada & Waspada \\
\hline
\end{tabular}


Tabel 7. Akurasi Minyak Bumi

\begin{tabular}{|l|l|l|l|l|l|l|c|}
\hline $\begin{array}{c}\text { Data } \\
\text { Tahun }\end{array}$ & Produksi & Konsumsi & GDP & Populasi & $\begin{array}{c}\text { Tingkat } \\
\text { Krisis }\end{array}$ & Klasifikasi & Real \\
\hline 2005 & 53.7 & 60.7 & 285.87 & 229.244 & 0.742 & Waspada & Waspada \\
\hline 2006 & 50.2 & 58.5 & 301.59 & 232.199 & 0.721 & Waspada & Waspada \\
\hline 2007 & 47.8 & 60.9 & 320.73 & 235.098 & 0.744 & Waspada & Waspada \\
\hline 2008 & 19.4 & 60.4 & 340.02 & 237.98 & 0.74 & Waspada & Waspada \\
\hline 2009 & 48.4 & 61.6 & 355.58 & 240.714 & 0.751 & Waspada & Waspada \\
\hline 2010 & 48.6 & 66.9 & 377.28 & 243.42 & 0.809 & Waspada & Waspada \\
\hline 2011 & 46.3 & 72.0 & 401.66 & 246.05 & 0.874 & Waspada & Waspada \\
\hline 2012 & 44.6 & 73.2 & 426.36 & 248.645 & 0.893 & Waspada & Waspada \\
\hline 2013 & 42.7 & 73.1 & 451.82 & 251.16 & 0.894 & Waspada & Waspada \\
\hline 2014 & 41.2 & 73.9 & 479.56 & 253.6 & 0.905 & Krisis & Waspada \\
\hline
\end{tabular}

Tabel 8. Akurasi Gas Alam

\begin{tabular}{|l|l|l|l|l|l|l|c|}
\hline $\begin{array}{c}\text { Data } \\
\text { Tahun }\end{array}$ & Produksi & Konsumsi & GDP & Populasi & $\begin{array}{c}\text { Tingkat } \\
\text { Krisis }\end{array}$ & Klasifikasi & Real \\
\hline 2005 & 67.6 & 32.3 & 285.87 & 229.244 & 0.589 & Waspada & Waspada \\
\hline 2006 & 66.9 & 32.9 & 301.59 & 232.199 & 0.859 & Waspada & Waspada \\
\hline 2007 & 64.4 & 30.7 & 320.73 & 235.098 & 0.484 & Waspada & Waspada \\
\hline 2008 & 66.4 & 35.2 & 340.02 & 237.98 & 0.484 & Waspada & Waspada \\
\hline 2009 & 69.2 & 37.3 & 355.58 & 240.714 & 0.484 & Waspada & Waspada \\
\hline 2010 & 77.1 & 39.1 & 377.28 & 243.42 & 0.589 & Waspada & Waspada \\
\hline 2011 & 73.3 & 37.9 & 401.66 & 246.05 & 0.407 & Waspada & Waspada \\
\hline 2012 & 69.4 & 38.0 & 426.36 & 248.648 & 0.501 & Waspada & Waspada \\
\hline 2013 & 64.9 & 32.8 & 451.82 & 251.16 & 0.484 & Waspada & Waspada \\
\hline 2014 & 66.1 & 34.5 & 479.59 & 253.6 & 0.487 & Waspada & Waspada \\
\hline
\end{tabular}

Berdasarkan hasil uji coba aplikasi maka diperoleh hasil prediksi krisis energi batubara, minyak bumi dan gas alam di Indonesia seperti dijelaskan di atas. Aplikasi ini lebih unggul dibanding pengambilan keputusan yang lebih sederhana karena prediksi dilakukan secara otomatis berdasarkan empat variabel yaitu produksi, konsumsi, GDP dan Jumlah penduduk. Penambahan variabel GDP dan jumlah penduduk sekaligus sebagai masukan pada model fuzzy inferensi prediksi krisis energi di Indonesia juga belum dilakukan oleh peneliti-peneliti lain. Sehingga penilitian ini diharapkan dapat berkontribusi bagi ilmu pengetahuan.

\section{KESIMPULAN}

Berdasarkan penelitian yang telah dilakukan seperti dijelaskan pada bab hasil dan pembahasan di atas, maka dapat disimpulkan sebagai berikut:

1. Sistem Inferensi Fuzzy dengan model tsukamoto telah terbukti mampu melakukan klasifikasi untuk masalah krisis energi pada minyak bumi, gas alam, dan batubara terhadap parameter produksi, konsumsi, GDP dan penduduk.

2. Sistem yang dibangun menghasilkan tingkat akurasi pada Minyak Bumi 90\%, Batubara 100\%, Gas Alam 100\%. 


\section{SARAN}

Sesuai dengan hasil penelitian yang telah diperoleh, beberapa saran untuk penelitian selanjutnya dapat disampaikan sebagai berikut:

1. Penetapan fungsi keanggotaan dapat dilakukan dengan melibatkan banyak pakar untuk satu bidang keahlian, sehingga dihasilkan sistem yang lebih kompeten.

2. Mempersempit Studi Kasus menjadi daerah / wilayah tertentu maupun sektor-sektor yang akan diteliti.

3. Pengujian dapat dilakukan dengan menggunakan data yang berasal dari Dinas terkait.

4. Menambah variabel yang dapat mempengaruhi jumlah/nilai dari parameter sebelumnya atau bahkan hasil output dari sistem.

5. Membuat sistem yang mampu memprediksi nilai/jumlah parameter inputan dalam jangka waktu yang panjang. Sehingga bisa dilihat tren krisis energi dalam rentang jangka panjang untuk beberapa tahun kedepan.

6. Menggunakan topik lain misal Data Mining untuk memecahkan masalah ini.

\section{DAFTAR PUSTAKA}

[1] Fink, S., 2002, Crisis management: Planning for the inevitable, iUniverse, New York.

[2] Makhrani, 2012, Buku Ajar Geologi Minyak dan Gas Bumi FMIPA Universitas Hasanuddin, FMIPA, Universitas Hasanudin, Makassar.

[3] Istadi, 2012, Introduction to natural gas processing, FMIPA, Universitas Diponegoro, Semarang.

[4] World Coal Institute, 2005, Sumber Daya Batubara tinjauan lengkap mengenai batu bara, https://www.worldcoal.org/sites/default/files/coal_resource_indonesian.pdf, diakses tanggal 22 Desember 2015.

[5] Lailah, A., Wahyuningsih, N., Usadha, IGN R., 2012, Model Peramalan Konsumsi Energi dengan Menggunakan Metode Regresi Fuzzy untuk Dataset Kecil (Studi Kasus: Indonesia), Jurnal Teknik Pomits, Vol 1, No 1, Hal 1-6

[6] Kusumadewi, S., Fuzzy multi-atribute decison making (fuzzy MADM), Penerbit Graha Ilmu, Yogyakarta.

[7] Sutojo, T., Mulyanto, E., \& Suhartono, V., Kecerdasan Buatan, Penerbit ANDI, Yogyakarta. 